\title{
Empowered Communities Tell Their Own Stories from Common Bean Production in Uganda
}

\subsection{Empowering Rural Women in Central Uganda to Achieve Higher Income and Improved Food Security with New Bean Varieties}

Most smallholder farmers in Uganda often opt to farm the more popular crops which include coffee, plantain, cassava, sweet potatoes, and maize. Smallholder bean farming in Uganda is however overtaking the crops as farmers are seeing the potential that bean farming possesses. Women in the traditional Ugandan setting are considered as care givers and are tasked with ensuring food security. In Northern Uganda for instance, women are not entitled to inheriting land. When it comes to land sharing, women are only allowed to endorse the sharing. They are however given a portion where they can plant crops they can utilize in the household. The Tropical Legumes projects however strived to eradicate the stereotype that exists with the position of women in production for commercial purposes (Fig. 5.1).

The 50-year-old Marycian Nakaniako (Fig. 5.2-5.4) just like most farmers in Uganda previously utilized most of her land to farm Plantain, sweet bananas, coffee, and sweet potato; she however spared a little piece of land to plant yellow bean for household consumption. Nakaniako who hails from Kateera Village has noticed a significant improvement in yield with the improved varieties of beans she has adapted. Marycian, a seed producer, owns 5 acres of land but utilizes three acres for the production of improved bean. Before switching to the improved varieties, she only utilized 1 acre for bean farming.

The local varieties on her $1 / 4$ acre do not yield as much as her improved varieties; from $1 \mathrm{~kg}$ of old variety seed for instance, she harvests $7 \mathrm{~kg}$ as compared to the $20 \mathrm{~kg}$ she gets from $1 \mathrm{~kg}$ of improved varieties.

Selling the improved varieties seed is easy for Marycian as she is a member of Gomba Seed Producers' Cooperative which is a registered quality declared seed producing cooperative, that she joined in 2008. Before joining the cooperative, she sold her beans to merchants who did rounds in the village after harvesting season. "I sold my beans as grain to local merchants who bought it at a very low cost; a kilo 


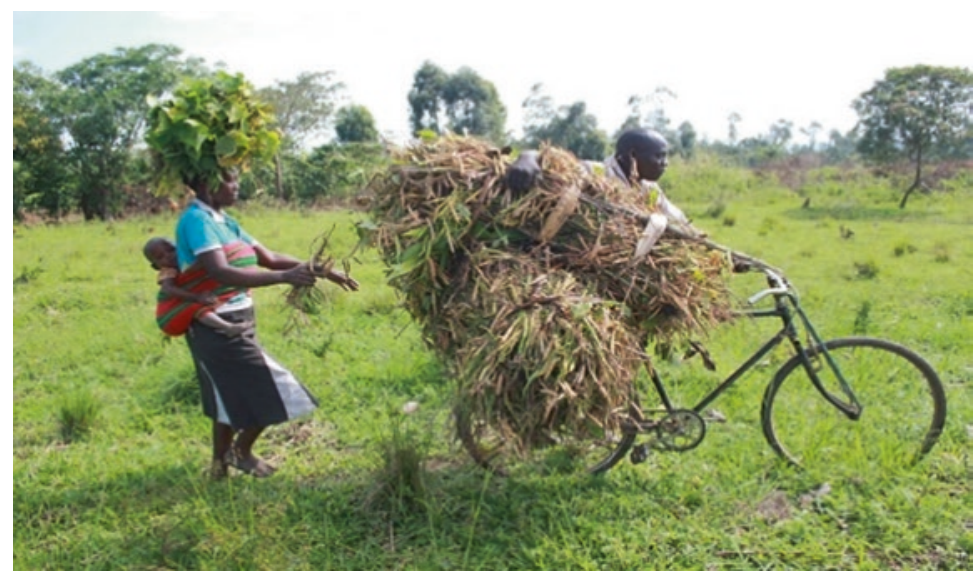

Fig. 5.1 Bean farmers in Masaka District transporting their bean produce to the homestead after harvesting, Uganda (Photo: Manyasa E)

Fig. 5.2 Ms. Marycian Nakaniako, a seed producer, owns 5 acres of land but utilizes three acres for the production of improved bean, Lwengo, Uganda (Photo: Manyasa E)

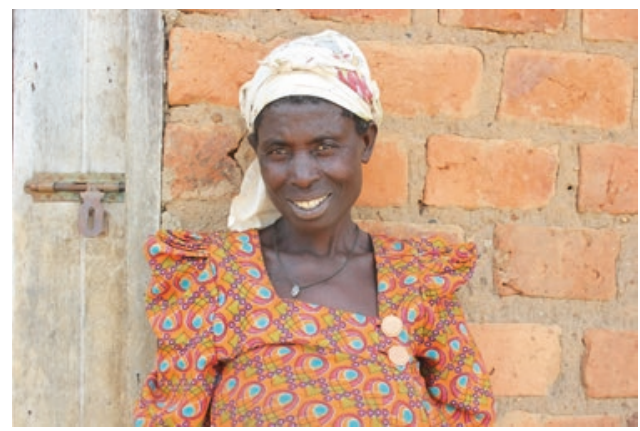

of common bean is sold to merchants at 1500UGX," says Marycian. Seed production has however seen Marycian sells the same quantity of quality seed for 2000UGX.

With the additional income from her production of quality seed, Marycian has noted significant changes in her social and economic status. For her, the greatest achievements besides constructing a new house and purchasing more land is being able to educate her disabled daughter.

My eldest daughter is deaf, she wasn't fortunate enough to enroll in a special school when she was a kid; she dropped out at primary seven due to lack of school fees, but with the money I get from producing seed, I was able to enroll her for a tailoring course in Kampala. I even bought her a sewing machine which cost me 500,000UGX which she uses to earn a living for her family. Beans are the highest contributor to my household income, I also farm some maize, but it requires a generous size of land before I get the same amount of money I make from beans every season. 


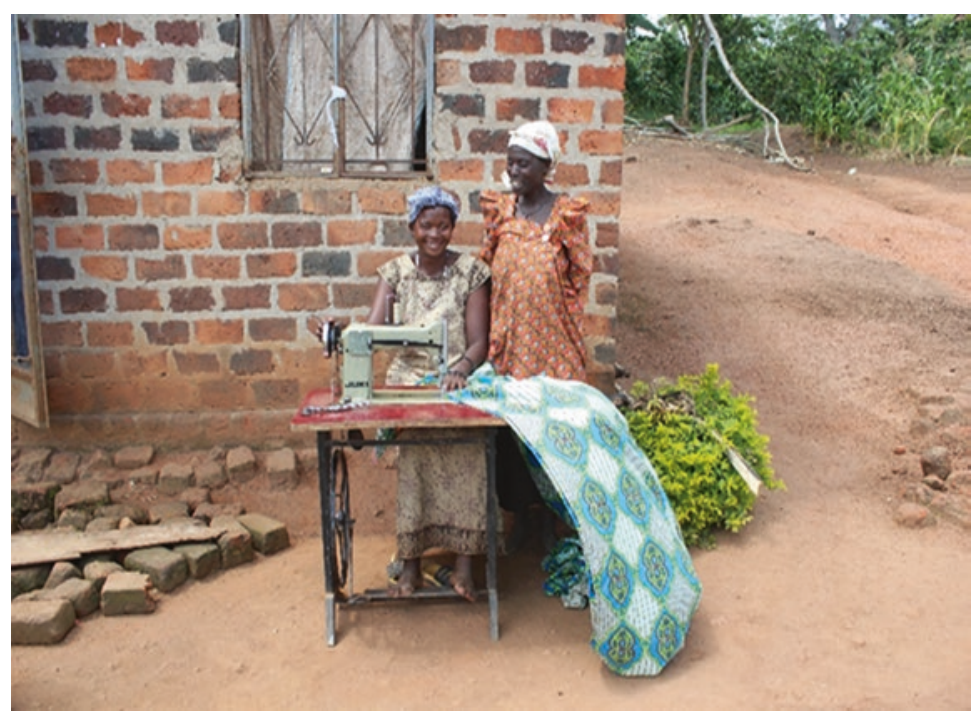

Fig. 5.3 Ms. Marycian Nakaniako and her daughter Rebecca Namugenyi with the sewing she purchased for her after selling her beans, Uganda (Photo: Manyasa E)

Fig. 5.4 Ms. Amida

Nabatanzi, a member of

Kyazanga Farmers'

Cooperative, Lwengo,

Uganda (Photo: Manyasa E)

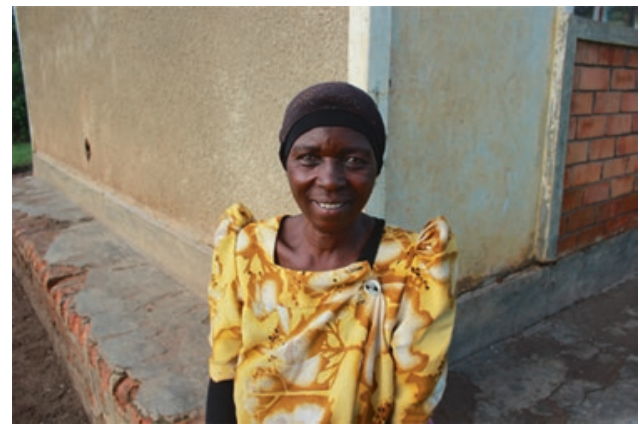

Ms. Amida Nabatanzi was married off at an early age, and after her separation from her husband, farming was the only source of income for her and her eight children. To make ends meet, she sold woven mats to her neighbors in Kalyamevuu Village in Lwengo District, Central Uganda, but the income was still insufficient to meet her family's needs. In 2015, impressed by how life had changed for her neighbors, she joined Kyazanga Farmers' Cooperative. Started in 1997 as a community group under Caritas Internationalis (MADO), the cooperative is a registered quality declared seed producer. "I was required to pay a membership fee of 20,000UGX before enjoying the groups benefits. After I paid the fee, came the planting season and I was given $7 \mathrm{~kg}$ of improved seed (NABE 15) to test on my farm." In addition to the improved variety seed, Amida received training on proper agricultural practices which include land preparation, line planting, spacing, crop management, and soil improvement. 
Amida admits that the skills she obtained from the training were invaluable. In the past, the bean she planted produced about $80 \mathrm{~kg}$, earning her less than 50,000 UGX. In the season that she tested the improved bean variety, she harvested over $250 \mathrm{~kg}$ of bean. "I barely got $80 \mathrm{~kg}$ before from bean farming but here I was getting more than $200 \mathrm{~kg}$," noted Amida. "I took my seed back to the cooperative which marketed it for me and paid me promptly." In the second season she planted $20 \mathrm{~kg}$ of NABE 14 and harvested $900 \mathrm{~kg}$.

The results from her first two seasons with the improved varieties of bean prompted Amida to increase her area of production; previously she utilized only $1 / 2$ an acre for bean farming, but she increased it to 2 acres. Amida is among thousands of farmers who have benefited from the Tropical Legumes projects; the additional income from her bean production has enabled her to educate her children up to university level. She has also purchased two goats that she uses for milk production. She is looking forward to purchasing a television set and open a savings account to enable her to repair her house and build a store for her bean produce.

\subsection{The Exciting Experience of Common Bean Seed Producer Cooperatives}

\subsubsection{The Successful Experience of Gomba Seed Producers' Cooperative, Gomba, Uganda}

Gomba Seed Producers' Cooperative, formerly known as Gomba Seed Farmer Group, was established in 2006 by 25 farmers from villages in Gomba District, Central Uganda. The district receives minimal rainfall and thus the main economic activity is livestock. The group has over time grown and has registered 300 quality declared seed producers. The bean varieties grown by the group are NABE 2, 4, 15 , 16, 2. The group procures seed from National Crop Resources Research Institute (NaCRRI) which they produce individually in their farms; they can sell the seed through seed companies and NGOs.

In a good season the group collectively produces over 200 tons of beans which is marketed together. The group is also the main supplier of beans to schools in Gomba and Mpigi Districts. They supply 50 tons of beans to schools in the two districts per season. Bean production has positively impacted the lives of many farmers in the groups. Most of them lived in grass-thatched houses but have now constructed permanent homes (Fig. 5.5). Some have bought bicycles, motorbikes, installed solar panels and bought electronics.

The group seeks to improve the livelihoods of community members and thus sometimes waive membership fees for members who can't afford and want to be part of the cooperative. These members are however loaned seed and the amount is recovered during sale. The group distributes quality declared seed to $90 \%$ of farmers in two subcounties where they are based. The sky is not the limit for Gomba seed cooperative as they have plans to build a bigger store due to their increased productivity every season. Plans are also underway to start seed processing and packaging for the group. 


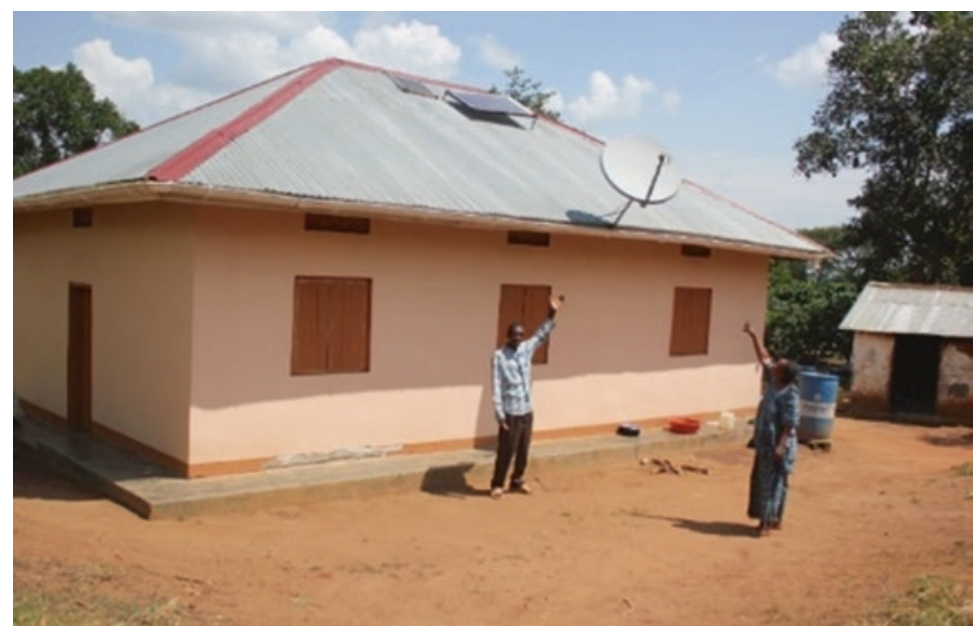

Fig. 5.5 Mr. and Ms. Mutegana David, members of Gomba Seed Producers, showcase some of the assets they purchased from profit he got from selling beans, Uganda (Photo: Manyasa E)

Working as a stationery dealer in Kampala was not enough for 50-year-old Lameck Kyebonere to meet his wife's and children's needs. For years, he was often away from his family and the little profit he made catered for rent of his shop and his food and accommodation in the city. Mr. Lameck abandoned his business and returned to the village to focus on farming. According to Lameck, farming is the best decision he ever made, and he is not looking back. Through Gomba Farmers seed producers, he acquired NABE 4, an improved variety of bean. Lameck prefers the new varieties as opposed to the old ones because they are high yielding, tasty, climate friendly, and have high demand in the market. Lameck's productivity has increased from $800 \mathrm{~kg}$ in one-and-a-half acres to $2400 \mathrm{~kg}$ from the same land size. From the profit he made from beans he has upgraded his house and built a drying yard for his bean (Fig. 5.6).

The 51-year-old Lule Daniel from Kateera village is a trained quality seed producer from Gomba District, Central Uganda. Initially, he produced bean but sold it off to local merchants as grain. In 2006, Daniel came together with 24 farmers and formed Gomba Farmers Group. The group received training from NARO and Victoria seeds, and the trainings have been beneficial in improving the groups' bean production. "I often used home saved seed during planting season, and I wasn't aware that the seed over time had become contaminated and susceptible to diseases and thus low yielding," explained Daniel.

The group was equipped with knowledge on land preparation, postharvest management, and pest and disease control. As a result of adhering to good agronomic practices, Daniel's productivity has tremendously improved; he previously managed to harvest $800 \mathrm{~kg}$ from two acres of land, but now from the same size of land, he harvests approximately 1.4 tons of improved bean. Daniel produces NABE 4.

Apart from beans, Daniel also farms maize, bananas, and coffee but beans contribute highest to his household income. He has built a permanent house and 

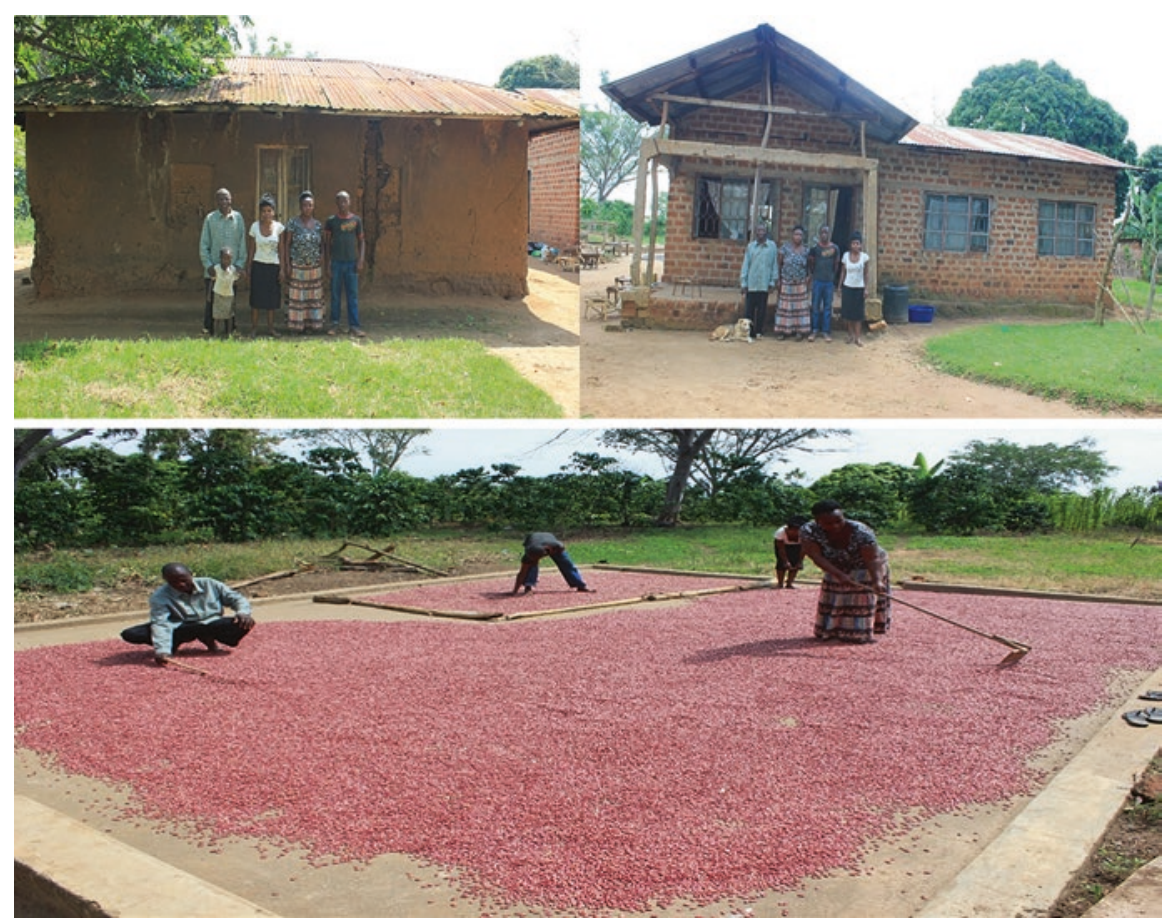

Fig. 5.6 From top left: Mr. Lameck and his family in front of his old house; top right: Lameck and his family in front of their newly constructed house. Bottom: Lameck on his drying yard, Uganda (Photo: Manyasa E)

purchased 8 acres of land from the extra income from beans (Fig. 5.7). His children have also been enrolled in high-quality schools in the District. He hopes to purchase a car in the coming year to enable him to move around the village efficiently as he was elected chairman of the group because of his industrious nature.

\subsubsection{Improving Livelihoods of Smallholder Bean Farmers in Uganda: The Success of Kyazanga Bean Seed Farmer Cooperative}

Formed in 1997 as a community group under Caritas Internationalis, Kyazanga Farmers' Cooperative Society Limited has grown to be among the most sought-after bean producers in Lwengo District. The group started with 26 members and a capital of 1,000,000UGX. Currently, the group has 1088 registered members and is valued at 200,000,000UGX.

The group aims at improving the livelihoods of peasant farmers in the district. Working with NARO accorded the group with the opportunity of testing lines which were later released to the public. The varieties released include NABE 1,2, 3. The group has previously worked with other NGOs like AGRA to multiply improved 


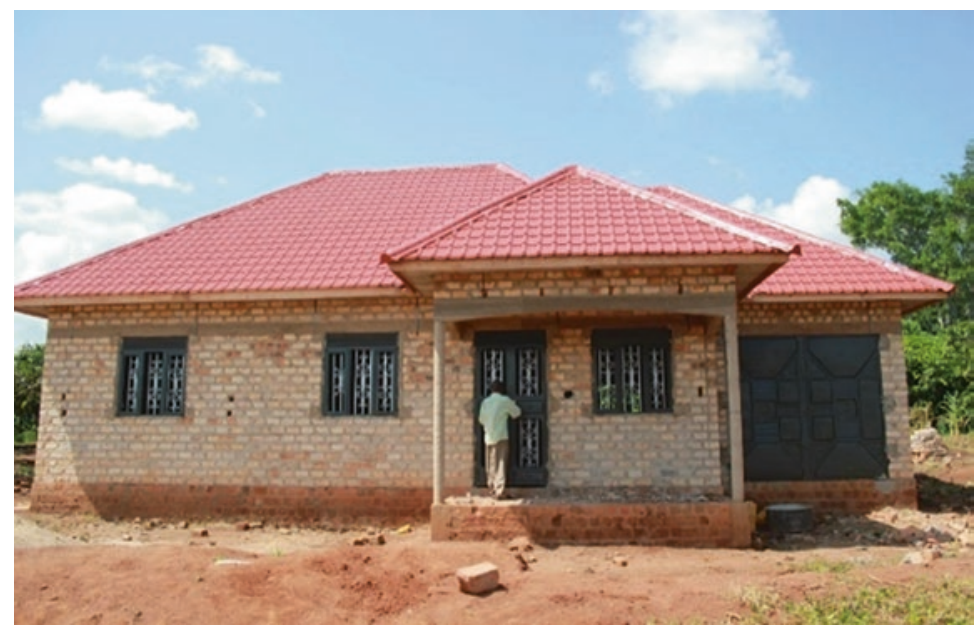

Fig. 5.7 Mr. Lule Daniel in front of his newly constructed house, Uganda (Photo: Manyasa E)

varieties. To enable proper management of the group, farmers have been organised in farmer groups; the cooperative collectively manages 60 farmer groups. Of the 1088 farmers, 400 are focused on seed production and 600 produce beans as grain.

To ensure high-quality seed is produced by the members, the group ensures that all the members receive adequate training on seed multiplication. They consequently conduct roadside demonstrations to create awareness and educate the community on the new varieties of beans available. This has contributed to high adoption of the improved varieties in the district. From the profit accumulated, the group has managed to employ qualified staff to help in managing the group. The group has also acquired assets and is putting on final touches to their new store which will hold more produce and new offices.

According to the groups' coordinator Joseph Asiime (Fig. 5.8), production of quality declared seed by the group is ensuring that farmers no longer access fake seed. They have also created a good market for beans for farmers due to their affiliation with seed companies and NGOs. The lives of farmers have improved drastically as the profit acquired from the production has enabled members educate their children, build homes, and some have even purchased motorbikes.

The cooperative hopes to register fully as a seed company to ensure they enjoy the full benefits of their hard work.

\subsubsection{CEDO Ensuring Access of Improved Varieties of Bean to Smallholder Farmers and Vulnerable Groups in Uganda}

Community Enterprises Development Organisation (CEDO) has played a significant role in converting beans to a commercial cash crop for the locality. The agroenterprise development organization seeks to develop the production and marketing 

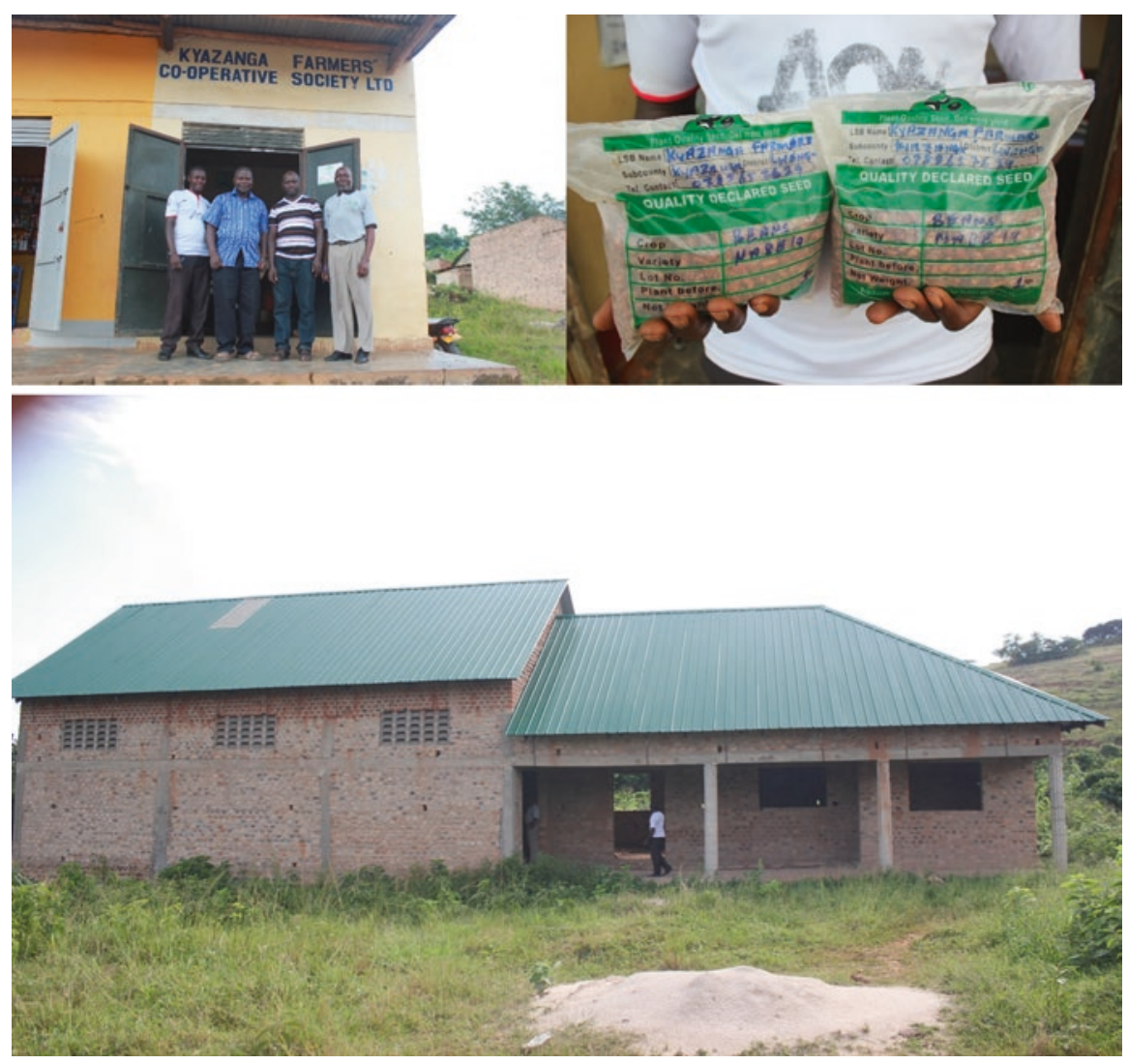

Fig. 5.8 From top: From left Mr. Begumisa Stephen, Mr. Gabriel Luyima, Mr. Aaron, and Mr. Asiimwe Joseph in front of Kyazanga cooperative offices. Quality declared seed produced by Kyazanga Cooperative. Newly constructed offices and store for the Kyazanga Farmers' Cooperative, Uganda (Photo: Manyasa E)

capacity of local communities. Uganda has more than 32 seed companies which deal with a variety of crops. Five of the companies deal with beans only, CEDO being one of them. The company has tremendously improved from producing $900 \mathrm{~kg}$ of beans to more than 450 tons in a season.

CEDO was founded in 2000 with an aim to improve nutrition and household food security for smallholder farmers and marginalized groups in the society. Women, children, smallholder farmers, and commercial farmers were the target groups for the IRISH foundation formed group; HIV was rampant in the area at that time. After the IRISH foundation left, they supported the group and it was registered as a community-based organization. In 1998, after the cassava mosaic disease and the banana wilt, the farmers had no backstopping crop which a cash crop would be, having mainly focused on cassava and bananas. This facilitated the increase in bean production as most of the farmers resorted to bean farming. In 2000, the group 
became a community seed producing group. With links from food processors in Kampala, selling the beans was not a burden to the group.

Initially the group produced quality declared seed (QDS), but when they discovered the seed companies were making more money from just processing the seed they sold to them, they were motivated to register as a seed company. The group followed up with the Ministry of Agriculture and were linked with NARO who came and provided guidance and support on methods of producing seed. The International Centre for Tropical Agriculture (CIAT) provided learning materials and seed and training ideas on marketing. Farm trials and demonstration fields were conducted by the research team from NARO, where farmers would learn bean farming practices. The farmers were also part of the participatory variety selection (PVS). The research team at NARO has played a vital role in the increase in bean production for CEDO. NARO sensitized them on parameters to follow when producing seed, offered trainings on different processes and brought in stakeholders from different disciplines. The enterprise has also been directly engaged with staff from the Ministry of Agriculture who assist them with inspection and standardization of their produced seed.

The enterprise started with two varieties in 2000 and as of 2017 they were producing more than ten varieties of beans. "Before 2007 we majored in one district, but we have now increased to 5 districts. We currently supply beans to 11 districts in Greater Masaka, and work more with women in bean production than men." The group chairperson narrated.

\subsection{Strengthening the Bean Breeding Program and Value Chain in Uganda}

The Tropical Legumes projects majorly aimed at enhancing capacity in the breeding sector. A lot of emphasis has been put in developing new materials from already existing germplasm. The bean breeding program work closely CIAT's program. CIAT owns the largest bean gene bank in Cali, Colombia.

Before 2012, there was hardly a bean seed system to talk about in Uganda, but this has changed over time. Tropical legumes contribute 30\% to the research program at NaCCRI. Initially the breeding program was haphazard," said Dr. Stanley Nkalubo.

Fig. 5.9). "We have moved from incorporating things randomly to straightening out breeding pipelines policy."

Digitization of data collection which was facilitated by acquisition of tablets with funds from Tropical Legumes projects has ensured data is not lost or distorted by the field technicians; they have also been adequately trained on how to use the gadgets. NaCRRI could only handle two traits at a time when it came to breeding new material but currently we handle close to ten traits at the same time. Annually the institution produces approximately $30,000 \mathrm{~kg}$ of breeder seed. 


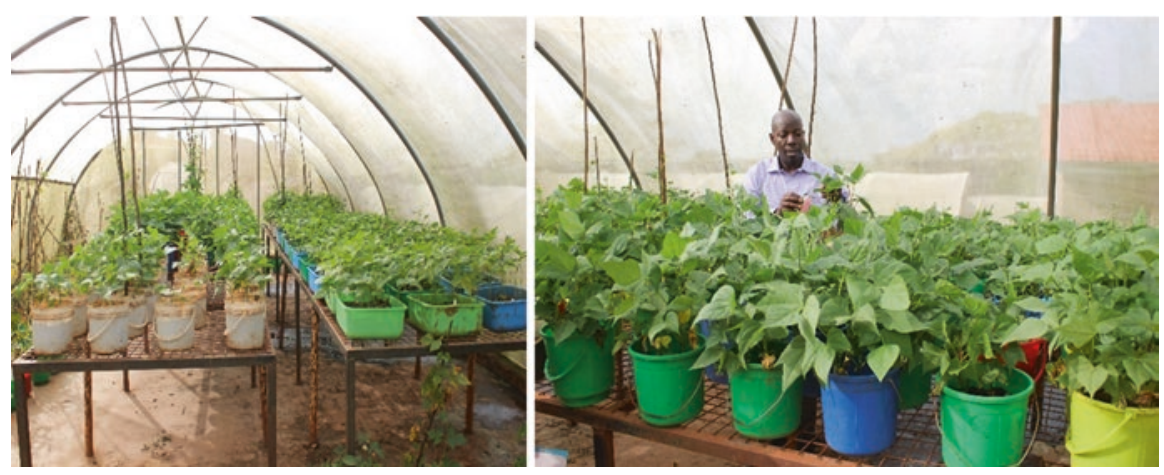

Fig. 5.9 Dr. Stanley Nkalubo in bean nursery at NaCCRI in Namulonge Uganda (Photo: Manyasa E)

Fake seed was a widespread problem in Uganda before the project started in Uganda. Most farmers did not have the capability to distinguish between fake seed and quality seed but over time, with trainings and being involved in the breeding process, the farmers are more knowledgeable. The seed system has also seen growth in seed companies as the program is working closely with seed companies (Pearl seeds and agro dealers in Uganda) to multiply the beans and ensure that farmers can have easy access to quality certified seed. Community seed multiplication has enabled farmers to easily access quality seed. The number of registered seed companies involved in bean production and distribution has gone up from 7 to 17 . The 17 companies work closely with the research institute at Namulonge.

Through the research institute, more farmers have been reached by extension officers. TL is keen to empower women in their projects, and over the years, women involvement in bean production has been notable. Gabriel Luyima, a researcher at $\mathrm{NaCRRI}$, notes that when women are involved in production there is less wasteland; this translates to more income for the family. Like in many households in Africa, the woman ensures food security for the family, and thus when involved, she will ensure that there is enough produce to feed the household and some for sale. Through sensitization, the women in Uganda have a different perception on beans; before it was merely for consumption, but it since has changed and they now look at it as a commercial commodity. The women now have a voice of their own, are more confident, and have gone a notch higher to even speak at major meetings (e.g. conferences) on the importance of bean production. The yield gaps between men and woman has also significantly reduced over time.

Benchmarking activities between farmers which were organized by the project has made them more exposed and knowledgeable. They have in addition learnt the nutritional benefits of the improved bean varieties. The yield has gone up for both the male and female since the inception of the project; pregnant women now utilize beans as supplements for zinc and iron. 
A total of 13 varieties have been released and promoted through the Tropical Legumes projects. NABE 15 for instance was released in 2010 through Tropical Legumes II, the variety has been up-scaled to South Sudan and Northern Uganda. Two more varieties which are high iron and zinc are in the pipeline and will be released in due course.

Open Access This chapter is licensed under the terms of the Creative Commons Attribution 4.0 International License (http://creativecommons.org/licenses/by/4.0/), which permits use, sharing, adaptation, distribution and reproduction in any medium or format, as long as you give appropriate credit to the original author(s) and the source, provide a link to the Creative Commons licence and indicate if changes were made.

The images or other third party material in this chapter are included in the chapter's Creative Commons licence, unless indicated otherwise in a credit line to the material. If material is not included in the chapter's Creative Commons licence and your intended use is not permitted by statutory regulation or exceeds the permitted use, you will need to obtain permission directly from the copyright holder.

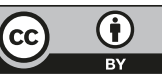

